\title{
THE CONTROL OF SIGATOKA (BANANA LEAF SPOT DISEASE) BY MIST-BLOWING WITH BANACOBRE-SANDOZ ${ }^{1}$ )
}

\author{
D. TOLLENAAR
}

\section{SUMMARY}

From the first appearance of Sigatoka on Hacienda Clementina, Ecuador, its spreading and intensifying were watched. At the beginning of the wet season the disease was spread by airborne ascospores, that were carried by the prevailing wind and jumped to new areas, mainly infecting the bananas along roads and open spaces. During the second part of the wet season the disease intensified, where it had arrived, by the waterborne conidia. During the dry season no new infection occurred, as there was no period with at least 18 hours of $100 \%$ humidity. Approximately 2 years after a first infection was observed, the plantations concerned ceased to produce exportable fruit.

Control of Sigatoka by fungicides is based not on protection of the susceptible two youngest leaves of every plant, but on checking the production and viability of conidia produced on spoots of older leaves. The effectiveness of combating is therefore favoured by an even distribution and proper sticking of an active, finely dispersed fungicide. To achieve this a special mist-blower was developed with a pipe $8^{1 / 2}$ metres high, from the top of which a fine mist of $3 \%$ Banacobre-Sandoz (an excellently sticking, finely dispersed cuprous oxide) was blown with airpressure on to the upper leafsurfaces of one or two banana rows on both sides.

The size $(50-100 \mu)$ and velocity of the droplets determine proper penetration, sticking and distribution. Drops from high-volume sprayers, even when sprayed under high pressure through nozzles, remain too large to be economical. In the case of fogging (drop size below $50 \mu)$ penetration and adherence become insufficient, because after ejection, such minute droplets lose speed very soon and then drift away on air currents without being properly deposited. With this small drop size, water also has to be replaced by oil in order to prevent evaporation.

The results obtained by mist-blowing only 100 litres of $3 \%$ Banacobre-Sandoz per hectare in regular three-weekly or monthly cycles, proved to be very satisfactory. Control was achieved, preventing any loss of fruit, whereas the untreated check was badly attacked and ceased to produce exportable fruit. Taking into account the excellent sticking qualities of Banacobre, the intervals between successive sprayings might even be further lengthened. By this method of mist-blowing, spraying expenses are reduced to only one fourth of those of high-volume Bordeaux spraying. At the same time washing of fruit becomes unnecessary.

\section{INTRODUCTION}

Effective control of Sigatoka in Central America has only been succesful with highvolume spraying of Bordeaux mixture, using approximately 2000 litres of liquid per hectare per spray. To achieve this, a pipeline system had to be installed, which is only possible in the case of large blocks of 200 hectares or more. This system is therefore attractive for big estates, and even then, its expenses are often prohibitive in countries like Ecuador, where the cost price of bananas cannot be as high as in Central America, because of higher freight to the U.S.A.

I was able to try out low-volume spraying with a mist-blower, and to introduce an excellently sticking coprous oxide, Banacobre-Sandoz on a Swedish estate in Ecuador, Hacienda Clementina, that paid the cost of the experiments. This new mist-blowing technique may change the whole picture of the economy of big banana estates and give smaller farms opportunities of controlling Sigatoka.

I am indebted to Dr E. W. B. v. D. Murzenseng, Head of the Institute of Horticultural Technique, and to Dr A. F. H. Besemer of the Plant Protection Service, both at Wageningen (Holland), who advised me on mist-blowing and fungicides in connection with the combating of Sigatoka.

1) Received for publication December 10, 1954. 
J. F. D. Bruinsma, a technician and owner of a fruit orchard at Dodewaard (Holland), who played an active part in the development of mist-blowers in Holland, was appointed by the Swedish company to carry out the experiments on Clementina. Special banana mistblowers were developed by "Constructiebouw Haring N.V." at Boskoop (Holland) in close cooperation with Bruinsma.

\section{Present KNOWLedge of THE DISEASE AND EXPERIENCE WITH ITS CONTROL}

\section{a Spreading of the disease through Latin America and damage caused}

Sigatoka was first recorded as a banana leaf spot disease in Java by ZrMmermanN (1902). It first arrived in the Caribbean in 1934 (WardLAW, 1934) and during the next few years it spread through the extensive banana areas of Central America. A few years ago it had spread as far South as the state of Sao Paulo (Brazil). After World War II, Ecuador was at first free of the disease, and thus got the chance to achieve a rapidly increasing production and to become the number one banana-exporting country of the world. But some years ago Sigatoka appeared in the northern part of that country (province of Esmeraldas), and now it has also reached the southern part, where Hacienda Clementina is situated.

The situation in Esmeraldas has already become very serious, and the disease is now a menace to the whole of Ecuador, unless a practical method of control can be developed.

The damage caused by the disease consists in leaf scorching, which reduces the assimilative surface. When the attack is very severe, the number of hands and the size of the fruit are reduced. But long before that happens, the quality of the fruit is affected in such a way that it has to be rejected, being no longer suitable for transport to countries overseas. Although the fruit may still look fairly normal, during the 1-2 days that elapse before it is loaded in the refrigerated steamer, it becomes soft and yellowish. And other fruit, although normal in appearance at the moment of loading, becomes soft and abnormally coloured during the refrigerated transport (premature ripening), thus causing big losses to the banana companies. Therefore as soon as an area becomes fairly seriously infected, the banana companies stop buying from the farmers in the whole district.

\section{$b$ Main features of the disease}

In Central America the disease has been studied by STahel (1937), WardLaw (1934, 1939), LEACH (1941, 1946) and by the scientific staff of the banana-growing companies. The modern work of LEACH has supplied detailed information on the disease; his work has greatly contributed towards explaining the main features. I shall give here a summary of the results of this research.

The fungus can develop two types of fructification: 1) sporodochia with conidia, and 2) perithecia, discharging ascospores. The conidia are usually produced on the upper leafsurface, and they are disseminated by dew or rain, which drips with conidia on unfurling heart leaves of plants below. By travelling downward along such leaves streak-wise infection may take place, resulting in line spotting.

Ascospores are expulsed from within the perithecia inside the spot, especially under conditions of heavy rain (dew is insufficient). These ascospores are airborne and, according to LEACH, they are mostly carried upwards by air currents, thus eddying around the tips of the lower leafsurfaces, causing an infection there, on the youngest two leaves, resulting in tip spotting.

Later on I will describe a third type of infection on young banana plants, which I shall call dot spotting.

As a rule spores are able to germinate and to cause infection only on the lower surfaces of the two youngest leaves. The upper surface very seldom becomes infected, not only because of the fewer stomata, but mainly because, immediately after unfurling, the upper surface becomes covered with a protecting epiphytic mycelial flora. The lower surface is not covered with this flora for the first 3-4 weeks after opening of the leaves, and this makes the lower surface of the first two leaves susceptible to infection, as a new leaf develops every 10-14 days. After a severe dry period, however, little or no covering with this flora may be present and then infection of the upper surface may take place as well and, in addition, more than two leaves may be susceptible.

The gummy residue exuded from fully developed spots, with which the dew becomes impregnated, has a toxic effect on the spores and also protects older leaves against further secondary infection. 
The first symptoms generally appear 4-5 weeks after infection. Under favourable conditions fructification will start approximately one week later, when the dark brown centre of the spot shrinks and begins to appear sunken. Dissemination of conidia is favoured by dew or light showers. The ejection of ascorpores takes place under humid circumstances, and is stimulated by heavy rains. The spores will germinate under the following conditions: temperature between $62^{\circ}$ and $85^{\circ} \mathrm{F}$, after constant rain and at least $18-24$ hours of $100 \%$ air humidity, and in the absence of antagonistic influences (such as epiphytic mycelial flora, gummy residue from old leafspots, or copper fungicides). The infecting hyphae travel round the edge of the leaf or across the leaf tissue to the upper surface, and appressoria are formed on both surfaces.

Perithecia remain potentially active in dead banana leaves, so called trash, hanging down the pseudostems or carpeting the ground.

The paak infection period of ascospores in Jamaica is described by LEACH as being correlated with heavy rainfall after a dry period. It is in accordance with the general fact, that fructifications of the perfect stage of a fungus are produced especially when conditions become less favourable for the fungus, that, at the beginning of the dry season, perithecia are formed, leading to ascospores formation from the trash at the beginning of the next wet season. And the same can be said of the tendency, described by LEACH, for more perithecia to be produced per unit area when massed spotting occurs and a large part of the leaf is killed. If, by spraying, the intensity of spotting can be kept low, indirectly also production of ascospores during the wet season will be reduced.

\section{c Mode of action of fungicidal spray}

Before the trials with Banacobre-Sandoz started, only Bordeaux (mostly 5-5-50 Bordeaux mixture to which a sticker was added) had been used on a commercial scale as a spray to combat Sigatoka. Large quantities of this mixture (approximately 2000 litres per hectare per cycls) are sprayed, especially on to the upper surface of the leaves. As a rule it is sufficient to spray every 3 weeks. LEACH has clearly demonstrated that spraying prevents the sporulation of sporodochia and the germination of conidia, but does not protect the leafsurface against infection by ascospores or conidia. This explains why spraying of the upper surface of the leaves can be successful athough this upper surface is hardly ever susceptible to infection. It also explains why such spraying fails to control ascospores infection, i.e. because formation of perithecia and ejection of ascospores cannot be affected by this method of spraying, as the fungicide does not come into contact with the ascospores.

\section{What THE INITIAL SPREADING OF SigatoKa ON CLEMENTINA TAUGHT}

The banana area of Hacienda Clementina, Ecuador is situated in the tropical lowland at the foot of the Andes, approximately 10 metres above sea level, on alluvial young volcanic deposits of excellent texture. There is a rainy season from Christmas until June, with a rainfall of 1200-2200 $\mathrm{mm}$, and a definite dry season during the second half of the year, without rain, but with overcast weather and very little sunshine ("garua"). This area at the foot of the high Andes is further characterized by the absence of winds of any importance during any period. The banana variety grown is Gros Michel.

In February 1952 the staff of Clementina reported the first signs of Sigatoka on two separate spots, $\mathrm{A}$ and $\mathrm{B}$, both near the western border of the hacienda. In March and April 1952 there were approximately $1 \%$ or less plants with some Sigatoka spots on an area of about 20 hectares. The attack looked very harmless and no one was concerned about the appearane of the disease.

By November 1952 the situation had already changed for worse. In the sections $A$ and $B$ the disease had enormously intensified. In both areas now a centre of infection could be observed, in which $80-90 \%$ of the plants were infected, and around it were concentric rings of less infection (Fig. 1). It was clear too that the spreading of the disease in this area had been favoured by roads and open spaces.

Outside this centre of infection, in the direction of the prevailing, very weak 
winds, was now an area of about 50-100 ha, in which here and there a plant with an infected leaf could be found (on $1 \%$ or less of the plants). This area was more or less in the position in which the now badly diseased area had been at the beginning of the year. Here, too, it became very clear that the infection proceeded preferably along the roads, following the main direction of the wind.

In addition to this, in areas $\mathrm{C}$ and $\mathrm{D}$, both along a major road, many miles away from the centre of infection, a few plants were discovered showing the first signs of Sigatoka. The few spotted leaves in these blocks, over 200 ha in size, were carefully destroyed.

It was also very remarkable that, even in the worst affected areas, the youngest 10 leaves of all the plants were completely free from Sigatoka spots at the end of November. This indicated that, as a new leaf unfurls every 14 days during the dry season, no fresh infection had taken place in the last period of $10 \times 14$ days. The same was observed in 1953 and 1954. Although no new infection takes place during the dry season and the plantations look healthy at the end of it, as all the young leaves are free from spotting, the brown trash is full of old spots, which contain a big potential of perithecia, ready to produce ascospores as soon as the rainy season starts.

During 1953 Sigatoka continued tot develop. The whole area of A and B became $100 \%$ infected during the first half of the year (wet season), and the first infected area of 20 ha went out of production in the middle of the year, as the quality of the fruit then became affected by the disease.

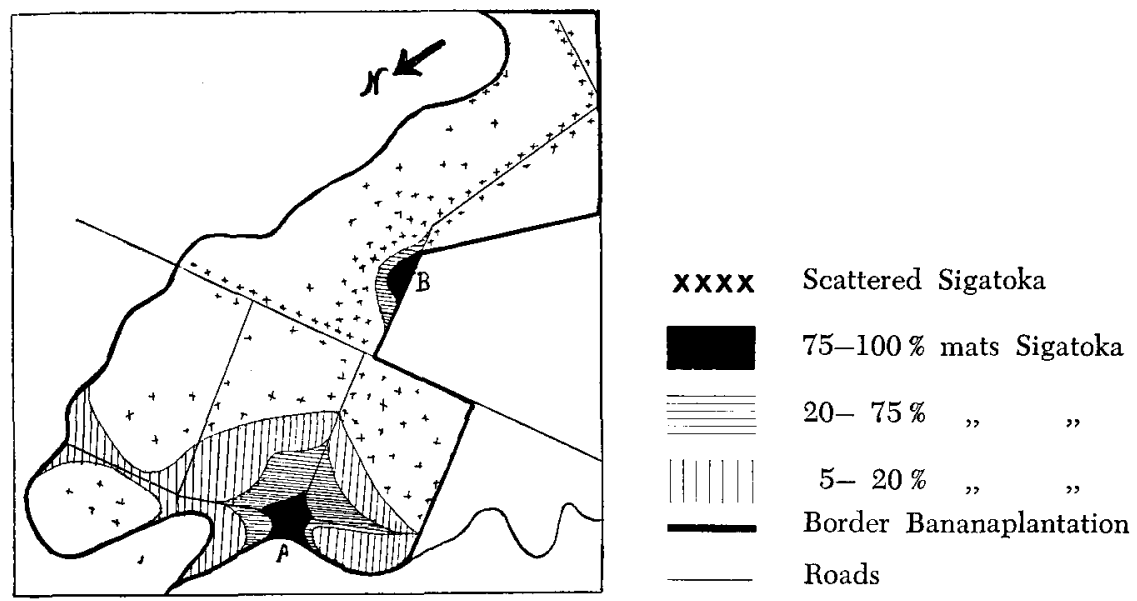

Fig. 1. Spread of sigatoka on hacienda clementina, nov. 1952 (Scale $1: 40.000$ ).

H. JönGENSEN, who had been searching for ascospores since May 1952, but without success, fond that ascospores appeared in large quantities after the beginning of the heavy rains, during February and March 1953.

In the areas $\mathrm{C}$ and $\mathrm{D}$, where the few infected leaves had been destroyed before the rains, the incidence of the disease remained very limited. Moreover, the disease developed there so slowly in the course of 1954, that it may be expected, that even in 1955 it will not be necessary to spray in order to prevent loss of fruit. It is quite clear that, owing to the increasing infection year by year from 
surrounding banana areas, that have become seriously diseased, it will be impossible to keep the disease down by destroying (stripping off) diseased leaves. Nevertheless, in the first stage of the disease's appearance, such stripping can help to postpone losses of fruit for one or two years.

In this connection I would mention the results obtained by stripping in experiments conducted by Simmonss $(1933,1939)$ in Australia. The stripping was carried out in small blocks of 3 rows of 24 plants each. The spotted leaves plus two healthy ones per plant were destroyed. Although this could not keep the disease down in the blocks, the row farthest away from the untreated control plants looked better.

This close observation of the first penetration of Sigatoka into a healthy banana area is of interest in connection with knowledge of the disease and its control. I might summarize the main features as follows.

Probably at the beginning of the wet season of 1951, some centre of infection west of the Hacienda, must have produced ascospores which, carried by the weak western breeze, infected two separate spots, one situated on the western border of block A and one on the southwestern border of block B. During the rest of the wet season of 1951 Sigatoka intensified on both these limited areas by conidia without spreading to new arreas (conidia are waterborne). in the following wet season, 1952, when the disease was noticed for the first time, numerous ascospores must have been produced during February and March, which infected new areas east of the old centres. Afterwards it became obvious from the intensity of infection that the transportation of ascospores was very much favoured by roads, which functioned as draught channels and along which much more infection was caused than inside the closed plantations (Fig. 1). In addition, two spots far away, but both along a road, acquired their initial infection from ascospores. During the rest of the wet season the disease was intensified by conidia, without spreading further. Thus the intensity of the first infecion became fixed and revealed itself in November, 1952, as concentric rings with infection decreasing from the inside outwards. At the end of the following rainy season (1953) the area, probably infected some 2\% years before, ceased to produce exportable fruit.

During the dry season no new infection takes place on Clementina, and at the end of it, the plantations look rather healthy, but immediately after the beginning of the rains, from the brown trash with old spots large numbers of ascospores are produced. The farmer, who was soothed during the dry season, is surprised and overwhelmed by the enemy a few months after the beginning of the rains.

In this part of Ecuador, there is a period at the beginning of the wet season, when the disease spreads and jumps with the wind to new areas (by means of ascospores), and a period during the second half of the wet season, when it mainly intensifies (by means of conidia). During the dry season all infection ceases.

Dot spotting is characterized by rather scarce, but large-sized spots (Fig. 2) and by its incidence in very young plantations.

The big, oval shape of the dot spot is determined by the shape and anatomy of the leaf of a very young banana plant. The later, normal leaves are long and elongated, they have fibrous veins, running parallel and close together, which 


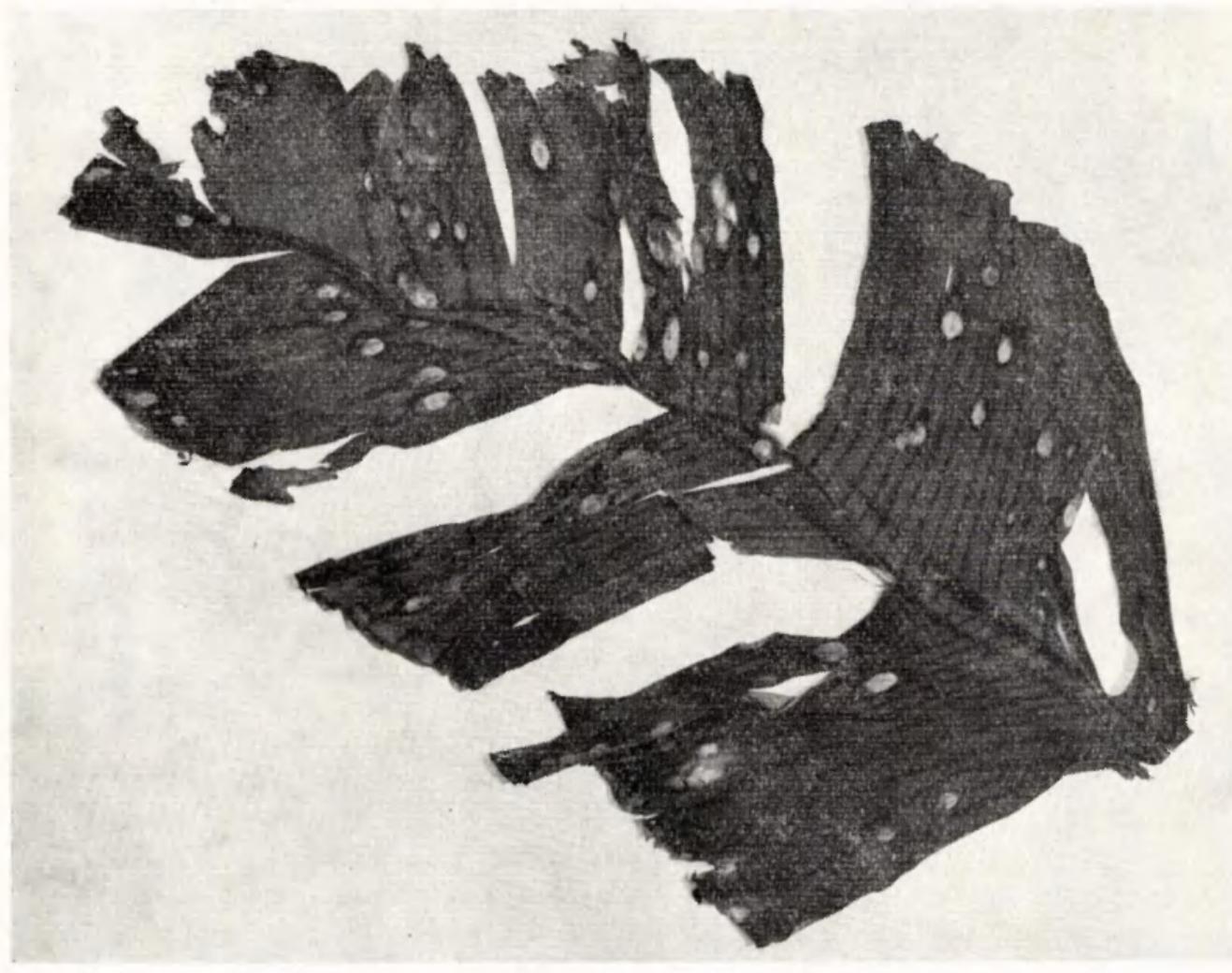

Fig. 2. Dot spotting, BesultiNg FRoM ASCOSPORE INFECTION IN A Young, OPEN BANANA PLANTING. ( $/ 3$ of natural size).

$2^{\text {the }}$

offer resistance to the transverse growth of internal infecting hyphae and cause small elongated spots to develop. But the first leaves of young banana plants, growing unshaded in the open field, are oval-shaped; these leaves have fewer veins, and the laminae consist for the greater part of parenchymatic tissue, a factor which emables the infecting hyphae to grow out, less hampered, in all directions, and which results in big, oval spots (Fig. 3).

In a young plantation the small banana plants are open on all sides; their leaves spread low above the ground, which is mostly covered with grasses, thus creating a special microclimate, characterized by a sharp fall in temperature during the night, causing heavy dew. Such young plantations on Clementina, when situated to windward of infected plantations, manifested this phenomenon of dot spotting. The first place, where I saw it was on "Lomites", a "Standard Fruit" plantation in Honduras. Mr. ChuTe informed me that there had been no bananas on the area for 15 years and that this type of infection normally occurred in all young plantations surrounded by old ones, although young as well as old plantations were kept under regular spray control. But, he added, with regular Bordeaux spraying (of the upper leafsurfaces), commenced immediately after planting, the disease was always brought under control, when the bananas were growing up and gradually closing in.

The incidence of dot spotting can be explained as follows. Ascospores from diseased plantations rise with hot currents of air during the tropcial daytime. They are carried away by the wind, sometimes over a great distance, and as last descend during the cool night in other areas. There they may enter open young 

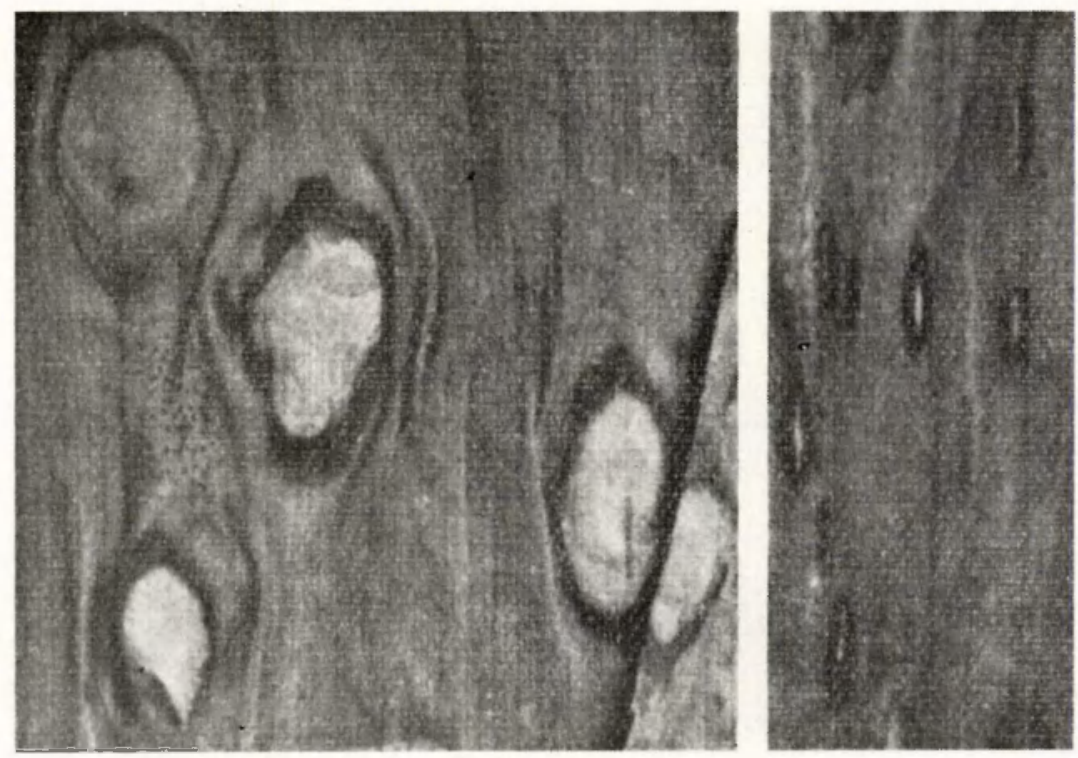

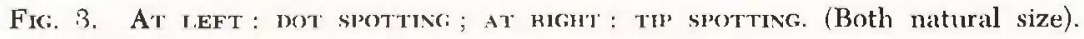

banana plantations (in rather small numbers) and get the chance to penetrate under the banana leaves, where they often finct a favourable microclimate. Closed plantations, as we have seen (Fig. 1), act as a screen against ascospore penetration, and thus the main type of infection inside old plantations is by conidia. This infection can be controlled by upper surface spraying. This explains why, after the plantations become closed, one is able again to control the discase by spraying.

In this connection I would draw the attention to the fact that ascospores and smoke (or dust) particles are of the same size. Dusting (acrosol) on a sunny day in an old bananal plantation gives us an idea of how the ascospores travel. When rising, the "concentration" is high (ascospores causing heavy tip spotting), but when it comes down far away, the density has become weak.

4 The type of mist blower ani) the fungicide that proved to be most surtable

To achieve effective control the upper surfaces of all the banana leaves must be covered evenly with a properly sticking active copper fungicide. The most important factors determining good and efficient control are therefore the drop size, the velocity at which the drops reach the leaves, and the properties of the copper fungicide.

Several experiments have shown that the drop size most suitable for these purposes is between 50 and $100 \ldots$. With a larger drop size liquid consumption increases rapidly, and appreciable amounts are lost by flowing off the leaves (high-volume spraving : drop size 150-400,", liquid consumption 1500-2500 l per ha). With a drop size smaller than 30 " (aterosol, dust, smoke) it becomes impossible to direct and force the droplets on to the leaves in such a way that they are deposited.

According to LATTA this depositing is a function of $\mathrm{D}^{2} \times \mathrm{V}, \mathrm{D}$ being the diameter and $Y$ the velocity of the drops. Thus, with decreasing drop size the 
velocity has to be raised rapidly, and for sizes below 30 " this exceeds practical limits. Moreover, small drops encounter so much friction from the air immediately after ejection, that they lose their speed and then, at the mercy of wind and air currents, are carried away without being deposited on the leaves in appreciable quantities.

Cuillet \& Guyot (1954), studying the problem of drop size in banana plantations of Guadeloupe, state that the drawbacks of too small a drop size are: "l'entrainement par les brises" and "la difficulté de la fixation sur un support". Although such a smoke screen or fog, when it moves through a plantation, may present an impressive spectacle, its fungicidal effect is always unsatisfactory, because of insufficient deposition, where it is necessary.

Merny (1954) determined the amount of copper deposited in banana plantations at a height of 0.75 to $1.50 \mathrm{~m}$, at intervals of 10 metres from the ejection point. Comparable amounts of copper were ejected as very small drops (fog. nébulisation) and as drops of approximately 50-100" (mist ; brouillard léger ; pulvérisation pneumatique) against and with the wind (wind velocity 0.7 to $1.2 \mathrm{~m} / \mathrm{sec}$ ). The deposition turned out to be as follows (Table 1). An amount of $5 \%$ per $\mathrm{cm}^{\prime}$ was considered as the minimum amount of copper metal necessary to effect sufficient control.

Table 1. Amount copper metal deposited ( $\gamma$ per $\mathrm{cm}^{2}$ of leaf). Average of several experiments. After MErinY.

\begin{tabular}{l|r|r|r|rrrr|r|r|r}
\hline & \multicolumn{4}{c}{ With the wind } & \multicolumn{4}{c}{ Against the wind } \\
At a distance of $\ldots \ldots \ldots \ldots$ & $10 \mathrm{~m}$ & $20 \mathrm{~m}$ & $30 \mathrm{~m}$ & $40 \mathrm{~m}$ & $10 \mathrm{~m}$ & $20 \mathrm{~m}$ & $30 \mathrm{~m}$ & $10 \mathrm{~m}$ \\
\hdashline With fogging $\ldots \ldots \ldots \ldots \ldots \ldots$ & 6.8 & 1.6 & 1.2 & 0.8 & 1.8 & 1.4 & 0.6 & 0.6 \\
With mist-blowing $\ldots \ldots \ldots \ldots \ldots$ & 47.0 & 2.4 & 1.5 & 1.5 & 12.5 & 1.9 & 1.8 & 0.9
\end{tabular}

The results of this experiment show clearly that, with mist-blowing (intermediate drop size), satisfactory deposition can be achieved at least 10 metres from the ejection point. But the fine fog (drop size less than 30 ,") just drifts away and it is not possible to keep deposition sufficienly in hand.

It is also a disadvantage of fogging that water has to be replaced by oil, because water evaporates before the very small droplets reach the leaves, and this increases sprayingcosts considerably. GuYot (1953) has obtained good control of Sigatoka by fogging bananas with such oily copper fungicide mixtures, but this fogging had to be carried out very 8 days, in order to achieve satisfactory coverage of the plantation with the interfering wind. Such frequent spraying, however, makes the cost prohibitive.

To produce the required drop size of 50-100 $/$ and to force these drops with sufficient speed on to the upper surface of the banana leaves, a special banana mist blower wes developed, which blows drops of this size, at an air pressure of $400 \mathrm{~mm}$ water pressure, from 6 outlets on top of an 8\% metre high tube downward on to two rows of bananaplants on both sides of the apparatus. With the ordinary pressure sprayers it is not possible to obtain this drop size and velocity.

A pilot "K.D.H." mist-blower, developed according to these principles by Bruinsma (Fig. 4) was used for experiments on a large scale on Haciende Clementina in 1954, and the results obtained were excellent (see section 5). Based on 


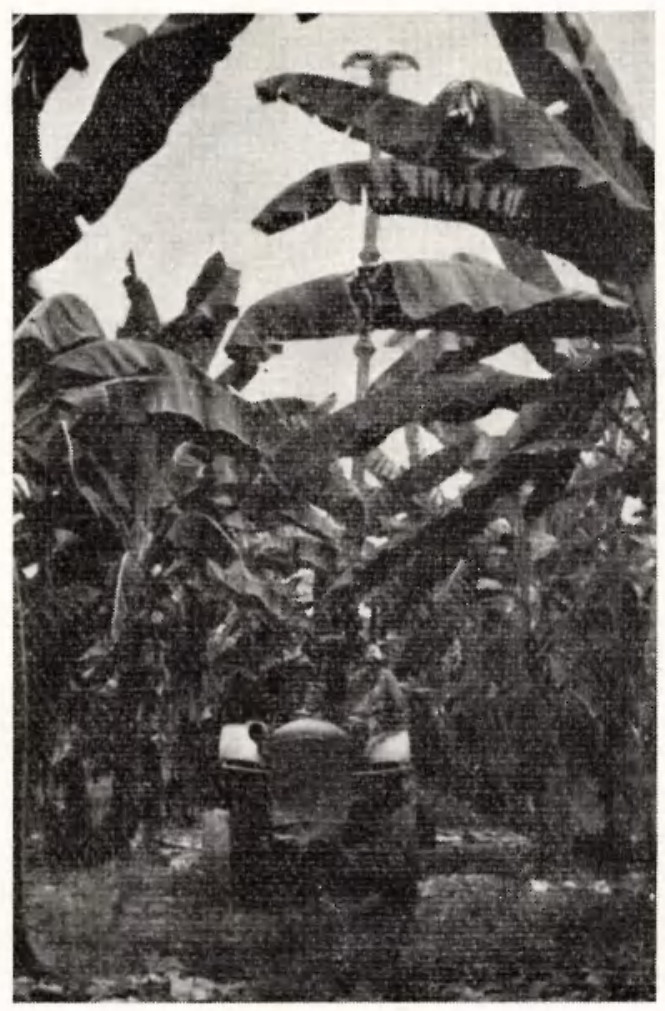

Fig. 4. Pilot mist Blower, operating IN BanaNa PLANTATION OF CI.EMENTINA.

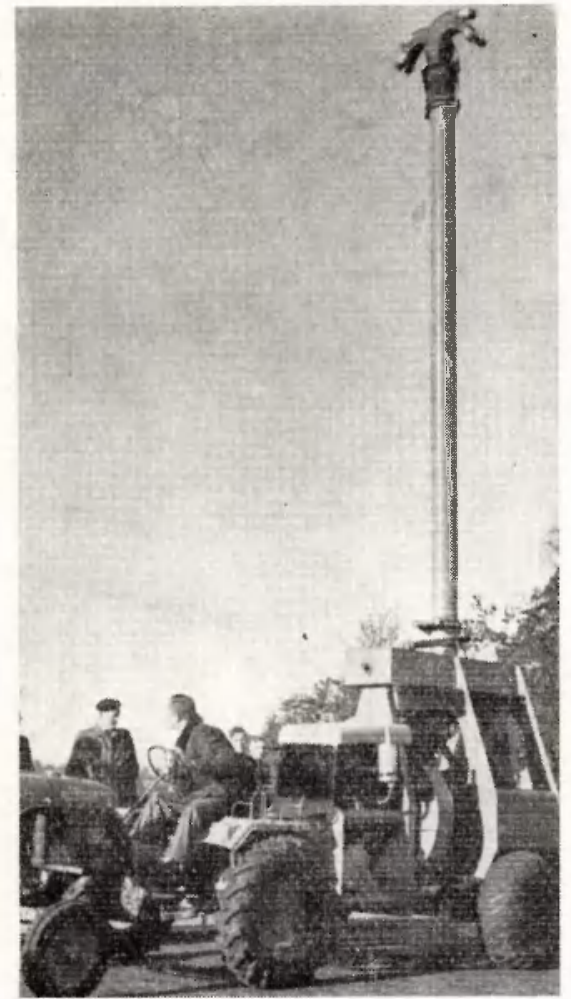

FIG. 5. "K.D.H." Banana Mist Blower,

this experience an improved, definite banana mist-blower was constructed (Fig. 5 and 6). This machine has a length of $3.15 \mathrm{~m}$ and a width of $1.32 \mathrm{~m}$; its dead weight is $2300 \mathrm{~kg}$ and it has a fungicide tank capacity of $700 \mathrm{l}$. It must be drawn by a tractor such as the Caterpillar D 2 or the International Harvester TD 6, and moves along every second or fourth banana row at a speed of $3-5 \mathrm{~km} / \mathrm{hour}$, spraying one or two banana rows on both sides, automatically, from 6 outlets, with a waterpressure at these outlets of $400 \mathrm{~mm}$. The actual capacity of the machine is 2-4 hectares per hour, and with a liquid consumption of 80-100 litres per ha a sufficient coverage of the banana leaves is obtained.

With this reduction of liquid consumption from approximately 2000 litres to 100 litres, the concentration of the fungicide has to be raised by 5 to 10 times. It is impossible, however, to spray Bordeaux mixture in a concentration of 5 to $10 \%$, and it became necessary tot try out other copper fungicides. The best results were obtained with Banacobre-Sandoz, a cuprous oxide containing a special sticker suited to the waxy banana leaves. This copper fungicide is characterized by very fine dispersion and excellent sticking qualities; even after heavy tropical rains, it is not washed off the banana leaves; it can be mist-blown easily in concentrations of $3 \%$ and higher. Other advantages of this fungicide are that the fruit does not need washing (as in the case of Bordeaux spraying), and that the tank and other parts of the apparatus are not affected by it. It is the combination of this special banana mist-blower with Banacobre-Sandoz as 


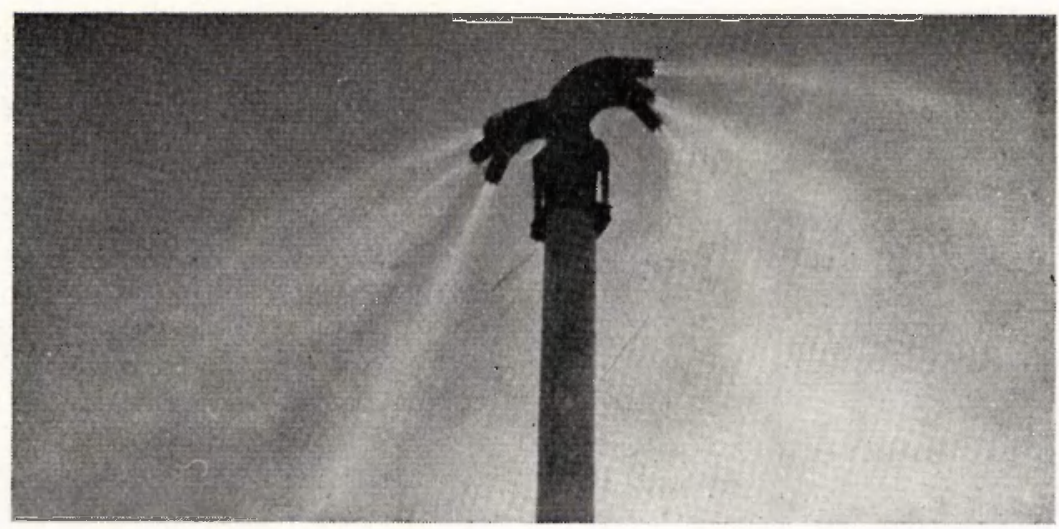

Fig. 6. "K.D.H." Banana mistblower; Detail of 6 mist-Blowing outlets,

fungicide that achieves effective control at much lower cost than that of the usual spraying with Bordeaux mixture.

\section{Results obtained BY Mist-Blowing With BanaCOBRE-SANDOZ}

In the banana area of Hacienda Clementina, where these experiments were carried out, Gros Michel is planted at distances of $5 \times 5$ metres.

The experiments started at the beginning of January 1954, when the first showers of rain occurred. Rainfall figures were as follows (Table 2).

Table 2. Rainfall on Hacienda Clementina from Oct. 1953-Sept. 1954.

\begin{tabular}{l|c|c|c|c|c|c|c|c|c|c|c|c|c}
\hline & \multicolumn{3}{|c|}{1953} & \multicolumn{10}{c}{1954} \\
\cline { 2 - 12 } & Oct. & Nov. & Dec. & Jan. & Febr. March & Apr. & May & June & July & Aug. & Sept. \\
\hline $\begin{array}{c}\text { Rainfall } \\
\text { in mm }\end{array}$ & 28 & 26 & 13 & 357 & 340 & 344 & 140 & 107 & 15 & 9 & 10 & 6 \\
$\begin{array}{c}\text { Number of } \\
\text { rainy days }\end{array}$ & 10 & 10 & 5 & 25 & 23 & 26 & 14 & 13 & 14 & 16 & 16 & 11 \\
\hline
\end{tabular}

The number of days with upwards of 18 hours of $100 \%$ humidity was highest in March, 1954.

The main experiments were carried out as treatments of 3-weekly cycles of 100 litres 3\% Banacobre-Sandoz per hectare. A block (I) of approximately 20 ha was treated in this way, and was compared with an unsprayed block (II) in the same area, which, before mist-blowing started in block I, was in the same condition; both blocks had been attacked severely by Sigatoka in the previous year.

Ten mats were marked for regular recording in the centre of each block: every 3 weeks the disease intensity was recorded on individual leaves of one unshot plant in each mat. The first 4 leaves are always free from spotting (incubation period), on the tenth leaf spotting reaches its ultimate degree of development. Records were therefore kept of the 5th to 10th leaves. The percentage of spotting was estimated, using the standards of LEACH (1946). 
Table 3. Mean percentage of spotting (mist-blown (I) versus untreated (II)).

\begin{tabular}{l|c|c|c|c|c|c|c|c|c|c|c|c|c|c}
\hline & \multicolumn{2}{|c|}{ Leaf no. 5 } & \multicolumn{2}{c|}{ Leaf no. 6 } & \multicolumn{2}{c|}{ Leaf no. 7 } & \multicolumn{2}{c|}{ Leaf no. 8 } & \multicolumn{2}{c|}{ Leaf no. 9 } & \multicolumn{2}{c}{ Leaf no. 10 } \\
\cline { 2 - 13 } & I & II & I & II & I & II & I & II & I & II & I & II \\
\hline Apr. 19th & 0 & 1.3 & 0.5 & 1.8 & 0.3 & 16.3 & 0.5 & 36.2 & 1.5 & 42.2 & 2.3 & 44.5 \\
May 3rd & 0 & 2.6 & 0 & 3.5 & 0.3 & 19.8 & 1.2 & 38.3 & 2.1 & 48.0 & 2.4 & 61.0 \\
June 3rd & 0 & 3.5 & 0 & 9.8 & 0 & 18.2 & 0.3 & 28.3 & 1.2 & 46.0 & 0.6 & 79.0 \\
July 3rd & 0 & 2.3 & 0 & 3.0 & 0 & 10.8 & 0.3 & $\mathbf{4 5 . 0}$ & 0.6 & 61.3 & 1.8 & 88.0 \\
Aug. 3rd & 0 & 2.6 & 0 & 3.0 & 0 & 12.0 & 0 & 38.2 & 0.6 & 60.0 & 2.1 & 92.5 \\
Sept. 3rd & 0 & 0.9 & 0 & 3.0 & 0 & 3.0 & 0 & 20.0 & 1.5 & 48.5 & 2.1 & 72.9
\end{tabular}

I : mist-blowing every 3 weeks with $10013 \%$ Banacobre-Sandoz per ha, from the beginning of January, 1954.

II : untreated, in the same area.

In the unsprayed block the spotting increased until the beginning of August ; the area ceased to produce exportable fruit. In the treated block spotting was almost completely suppressed, and accordingly there was no loss of fruit.

A similar comparison (IV : untreated, versus III : $100 \mathrm{l}$ Banacobre-Sandoz per ha every 3 weeks) was tried out in another block, the only difference being that, in the treated area, a few rows of bananas had to be left unsprayed, owing to the presence of drains, that prevented the machine to move there.

Table 4. Mean percentage of spotting (mist-blown (III) versus untreated (IV)).

\begin{tabular}{|c|c|c|c|c|c|c|c|c|c|c|c|c|}
\hline & \multicolumn{2}{|c|}{ Leaf no. 5} & \multicolumn{2}{|c|}{ Leaf no. 6} & \multicolumn{2}{|c|}{ Leaf no. 7} & \multicolumn{2}{|c|}{ Leaf no. 8} & \multicolumn{2}{|c|}{ Leaf no. 9} & \multicolumn{2}{|c|}{ Leaf no. 10} \\
\hline & III & IV & III & IV & III & IV & III & IV & III & IV & III & IV \\
\hline May 6th & 0 & 3.5 & 1.5 & 3.0 & 2.1 & 19.2 & $3: 0$ & 44.6 & 4.7 & 68.0 & 3.0 & 79.0 \\
\hline June 3rd & 2.1 & 6.1 & 2.7 & 14.8 & 4.7 & 31.3 & 4.7 & 51.6 & 4.7 & 53.3 & 9.8 & 78.3 \\
\hline July 3rd & 0 & 0.7 & 0.8 & 3.0 & 1.5 & 12.3 & 3.0 & 42.2 & 3.0 & 53.3 & 3.0 & 81.1 \\
\hline Aug. 3rd & 0 & 1.0 & 0 & 2.0 & 0 & 17.2 & 2.0 & 45.0 & 3.0 & 63.3 & 3.0 & 100 \\
\hline Sept. 3rd & 0 & 0.5 & 0 & 3.0 & 0 & 8.4 & 3.0 & 20.0 & 3.0 & 45.0 & 3.0 & 85.0 \\
\hline
\end{tabular}

III : mist-blowing every 3 weeks with $10013 \%$ Banacobre-Sandoz per ha, from the beginning of January, 1954.

IV : untreated, in the same area.

With the exception of a modest spotting peak in the treated block on June 3rd, the general picture is the same (compare Fig. 7). Althought this small peak was of no practical importance, as the disease was kept sufficiently under control to prevent any loss of exportable fruit, it indicates an infection in February/ March by airborne ascospores, produced by the few unsprayed rows. This again demonstrates the danger presented by untreated areas near and around sprayed areas.

Taking into account the fact that during the wet season on Clementina, a new leaf unfurls on unshot plants every twelfth day, the most serious infection can be calculated to have taken place during the second half of March and the first days of April 2). It was during that period that most days with 18 hours or more of $100 \%$ humidity were recorded in 1954 .

2) On the tenth leaf the maximum spot development was on August 3rd, so we may calculate the period of maximum infection by deducting $10 \times 12$ days, which brings us to the beginning of April. Another marked peak can be noticed on the sixth leaf on June 3rd. Deducting $6 \times 12$ days, we arrive at the second half of March as serious infection period. 
Since the effectiveness of control achieved in this way exceeded practical requirements, it seemed important from a practical point of view to ascertain the most economical intensity of mist-blowing. A block was therefore given 3 -weekly cycles of only $6013 \%$ Banacobre, and another block 3-weekly cycles of $10012 \%$ Banacobre per ha. Although control looked less complete in these cases, it nevertheless proved to be quite sufficient. But the result obtained in an area of about 20 ha, treated with monthly cycles of $10013 \%$ Banacobre per ha, was more promising. There, control was not less effective than with 3-weekly cycles. This shows the way to a possible further reduction of the cost of combating.

As regards Bordeaux spraying, practical experience has established the average interval between sprayings in Central America at 21 days. But during this interval about two new leaves unfurl on every plant and it is just those leaves that are susceptible to infection. This means that, applying the 3-weekly cycle, approximately $50 \%$ of all susceptible leaves are not covered with Bordeaux. In that respect a limited extension of the 21 days' cycle could not make the difference it actually does. LEACH (1946) made it clear that the function of the fungicide is not to protect the susceptible leaves but to check the production and viability of the conidia. So the limit of the 21 days' interval indicates, that after that period, under Central American conditions, the Bordeaux on banana leaves is washed off and/or exhausted. It must have been the excellent adhering qualities of Banacobre-Sandoz that made extension of the interval possible. In 1955 it will be investigated how far the interval can be extended without affecting good control, i.e. how long mist-blown Banacobre-Sandoz remains active on banana leaves under tropical rainy conditions.

\section{ThE ECONOMY OF MIST-BLOWING}

It is the consumption of fungicides that mainly determines the expense of a method of control.

With decreasing drop size (not falling below $50 \mu$ ), the effectiveness of the same amount of copper increases rapidly. Even in 1946 LEACH remarked: "In all these experiments, suprisingly good control was often obtained when practically no spray was seen to remain on the waxy leaf surface, the spores and germ tubes being presumably killed by the absorption of minute quantities of the fungicide when drops of the latter came momentarilly in contact with them on the dry leaf". This idea was systematically developed by covering the leaves evenly with minute drops of a fungicide, by mist-blowing Banacobre-Sandoz, in which the copper is in very fine dispersion. But when the drop size exceeds a certain limit the efficiency decreases again; too small drops do not adhere sufficiently.

In this connection a comparison is made between the costs of three systems. (large, intermediate, and very small drops ; high-volume spraying, mist-blowing, fogging), in the hypothetical case that regular spraying is necessary troughout the whole year, because of permanent wet weather. This comparison is based on the following data : 


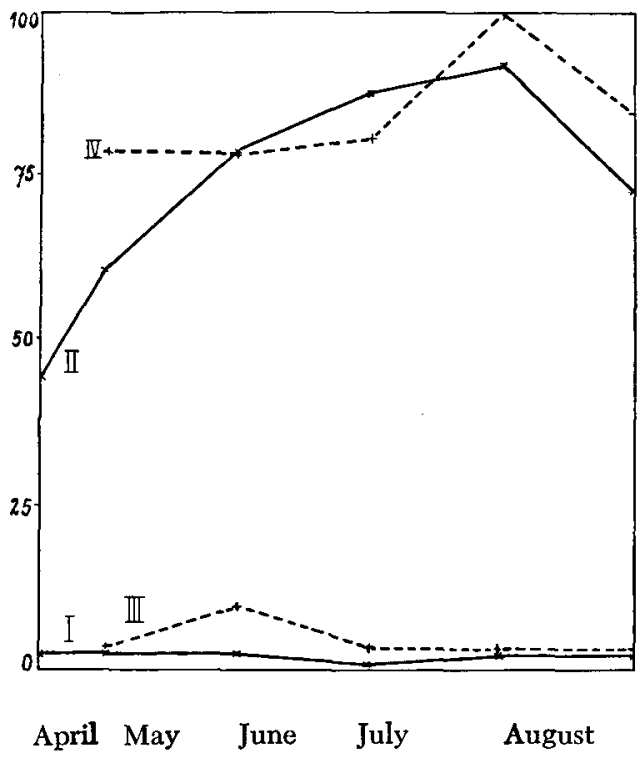

Fig. 7. Percentage spotting of 10th Leaf. II \& IV: untreated; I \& III : mistblower with $3 \%$ Banacobre-Sandoz.

High-volume spraying. Drop size $150-400 \mu$; liquid consumption $2000 \mathrm{l}$ of Bordeaux mixture 4-4-50 (1\%) per cycle per ha ; 17 cycles a year. The approximate costs are based on figures by VERNON, published by ALBAN (1952).

Mist-blowing. Drop size $50-100 \mu$; liquid consumption 1001 of $3 \%$ Banacobre-Sandoz per cycle per ha; monthly cycles. It might prove possible to extend the interval between two sprayings to 6 weeks, in which case the cost will further decrease. Cost price figures are based on experience of Clementina. Every mist-blower must be provided with a tractor, and every 3 mist-blowers with a supply tank car of $2100 \mathrm{l}$ capacity. One mist-blower is capable of covering at least 300 ha. All costs of maintenance of machinery, fungicide and labour, together with depreciation are included.

Fogging. Drop size less than $50 \mu$; liquid consumption 401 of oily copper

Table 5. Comparative costs of 3 systems of spraying.

\begin{tabular}{|c|c|c|c|c|c|}
\hline System & $\begin{array}{l}\text { Spraying } \\
\text { cycle }\end{array}$ & $\begin{array}{l}\text { Liquid con- } \\
\text { sumption per } \\
\text { spray per ha }\end{array}$ & $\begin{array}{c}\mathrm{Kg} \text { of } \\
\text { copper } \\
\text { metal } \\
\text { per } \\
\text { spray } \\
\text { per ha }\end{array}$ & $\begin{array}{c}\text { Kg of } \\
\text { copper } \\
\text { metal } \\
\text { per ha } \\
\text { per year }\end{array}$ & $\begin{array}{c}\text { Total } \\
\text { yearly } \\
\text { spraying } \\
\text { cost } \\
\text { per ha }\end{array}$ \\
\hline High-volume spraying & 3-weekly & $2000 \mathrm{l}$ & 5 & 85 & $\$ 200$ \\
\hline Mist-blowing & monthly & 1001 & $1 \frac{1}{2}$ & 18 & $\$ 50$ \\
\hline$\ldots \ldots \ldots \ldots$ & 2-weekly & $40 \mathrm{l}$ & $4 \frac{1}{2}$ & 117 & $\$ 490$ \\
\hline
\end{tabular}


oxychloride (22\% \%) per cycle per ha. According to Guyot $(1953,1954)$, at least one treatment every fourteen days is necessary. The cost price is based on figures given by the same author; the costs are unfavourably influenced by the use of oil as liquid.

In order to enable the machine to move in the plantation, it must be laid out in regular order and be regularly pruned. As far as soil conditions are concerned, movement of mist blower and tractor will present no special difficulties, as drainage has, in any case, to be adequate, otherwisse banana growing cannot be succesful. It will be necessary to arrange the system of drainage in such a way that no bridges (or very few) will be necessary. If roads run parallel, the machine should be able to enter along one road, and the collecting ditch should be built along the other road. The mist-blower will then be able to move up and down between the transverse drains without crossing any ditch or drain.

\section{REFERENCES}

Alban, O. A. : La Industria bananera en el Ecuador, Quito, 1952.

Cuillé, J. \& H. GuYot: Les traitements fongicides des bananeraies. Fruits d'outre-mer 9 (1954), 269-288.

Guyot, H. \& J. CuIllé: Les formules fongicides huileuses pour le traitement des bananeraies. Fruits d'outre-mer 9 (1954).

- - : La lutte contre Cercospora Musae dans les bananeraies de Guadeloupe, essais de nébulisation (fogging). Fruits d'outre-mer 8 (1953), 525-532.

- - : La lutte contre Cercospora Musae dans les bananeraies de Guadeloupe, essais de nébulisation (fogging). Fruits d'outre-mer 9 (1954), 293-296.

LEACH, R. : Banana leaf spot, Mycrosphaerella musicola, the perfect stage of Cercospora Musae Zimm. Tropical Agriculture 18 (1941), 91-95.

_ - : Banana leaf spot on the Gros Michel variety in Jamaica. 118 pp., Kingston, 1946.

Merny, G. : Essai de nébulisation et de pulvérisation pneumatique dans la lutte contre Cercospora Musae à la Guadeloupe. Fruits d'outre-mer 9 (1954), 297-301.

Simmonds, J. H. : Banana leaf spot. Queensland Agr. Journ. 34 (1933), 21-40.

- - : Influence of seasonal conditions on the development of Cercospora leaf spot of the banana, with special reference to the control programme. Queensland Agric. Journ. 52 (1939), 633-647.

Stahel, G.: Notes on Cercospora leaf spot of bananas. Tropical Agriculture 14 (1937), $257-264$.

Wardlaw, C. W. : The occurrence of Sigatoka disease (Cercospora Musae Zimm.) on bananas in Trinidad. Trop. Agriculture 11 (1934), 173-175.

- - : Cercospora laaf spot disease of bananas. Nature, 144 (1939), 11-14.

ZimmermanN, A. : Ueber einige an tropischen Kulturpflanzen beobachtete Pilze. Cbl. f. Bakt., Abt. 2 (1902), 2-19. 